Huber, Wolfgang ${ }^{1}$

Heidelberg University/Stellenbosch University

\title{
The dignity of the different - Towards a Christian ethics for a pluralistic society ${ }^{2}$
}

\begin{abstract}
From the perspective of three periods of professional experience of the author - twelve years as a church-related researcher, fourteen years as a full-time professor of ethics and sixteen years as a church leader - the essay expresses the need to address the role of Christian ethics for society anew. It shows how and why, in the next period of his research and public involvement, the author wants to take the pluralistic character of modern societies even more seriously than in some of his previous approaches. In order to do so and to reach some ethical agreement in pluralistic societies, a central prerequisite is to make room for different voices to be heard. For only then we shall find a relevant, overlapping consensus amongst these voices. This, furthermore, requires rethinking of the forces - religious or otherwise behind why human beings are motivated to act according to their ethical convictions. In all of this a useful guiding principle may be found in the so-called dignity of the different.
\end{abstract}

Normally one writes a paper first and decides on the title only at the end. Or one receives a title to speak on from the organiser of a conference that one should use. None of the two possibilities applies to the following text. I first chose the title myself and afterwards had to struggle with it. I present my reflections in four steps:

From practical ethics to ethical theory; ethics in a "time of many worlds"; from ethical plurality to pluralistic ethics; and, the dignity of difference or the dignity of the different.

\section{FROM PRACTICAL ETHICS TO ETHICAL THEORY}

To begin with, I will briefly sketch the three periods of my professional life and the different ways in which I had to do public theology in general and Christian ethics in particular in these three periods.

After my theological studies and sometime in the ministry I was for twelve years, beginning in 1968 , as a staff member and then the deputy director of a church-affiliated research institute, the Protestant Institute for Interdisciplinary Research, in Heidelberg. ${ }^{3}$

1 Wolfgang Huber is former Bishop of Berlin-Brandenburg in the German Evangelical Church in Germany (EKD), until his retirement in 2009. He is currently Extraordinary Professor of Theology at Heidelberg University as well as at Humbolt University, Berlin, and a Fellow of STIAS at Stellenbosch University, South Africa.

2 I presented this paper at the Stellenbosch Institute for Advanced Study (STIAS) on 4 March 2010. I am extremely grateful for the close co-operation with Dirk Smit who initiated the project on "Faith and Fabric" to which this paper belongs.

3 Forschungsstätte der Evangelishen Studiengemeinschaft (FEST). 
NGTT: Oopbron - http://ngtt.journals.ac.za

The question we had to address was, broadly speaking, how a Christian church can face the great challenges of our times, challenges we at the time saw as shaped by science and technology, by the presence of military means of mass destruction, by a growing global disparity between the North and the South. Together with some colleagues I concentrated in those years on two main topics, namely the Christian responsibility for peace and a Christian understanding of human rights (cf. Huber and Tödt 1977). The way in which Christian churches, as communities of faith, take public responsibility from that time onward became a constant feature of my academic work as well as of my practical involvement in the church.

That period was followed by fourteen years, beginning in 1980, teaching systematic theology, especially Christian ethics, at two German universities. How to teach Christian ethics academically became the question that I had to address. I had to deal with the fact that the canon of subjects in this field was, of course, very broad (both for the students and for me as a teacher), but rather narrow from the perspective of the on-going international debate on applied ethics as well as the thematic variety within applied ethics. In those years I concentrated again on the fields of peace ethics and the ethics of law (cf. Huber and Reuter 1990; Huber 1996). At the same time, I had the opportunity to gain a broader international experience. Among my deepest personal impressions during those years was the confrontation with apartheid in South Africa and with the ways Christian theologians dealt with this topic both academically and existentially. In fact, my friendship and co-operation with Dirkie Smit, John de Gruchy, Renier Koegelenberg, Etienne de Villiers and others goes back to that period. I mention with especial gratitude the many years of co-operation with Dirkie Smit, to whom I owe so many insights, suggestions and inspiration. For me he represents a truly reformed and liberated form of Reformed theology (cf. Smit 2009). His role in the writing and interpretation of the Belhar Confession (1982, as adopted by the General Synod of the Dutch Reformed Mission Church in 1986) clarifies in depth the relationship between Christian faith and political responsibility with regard to the equal dignity of every human person (cf. Cloete and Smit. 1984; Smit 2005: 355ff.; Naudé 210). ${ }^{4}$ The Belhar Confession made clear why Christian churches cannot be "neutral" with regard to such questions and why they cannot promote the forced separation of people on a racial basis..$^{5}$

For me personally, the encounter with the struggle to overcome apartheid in South Africa, as interpreted by people like Dirkie Smit, was an exemplary experience of the conviction that faith, ethics and the public witness of the church cannot be separated from each other. For me the lesson was: One cannot teach Christian ethics in an academic setting without practising what we teach in our personal lives and in public.

The way in which I was provoked to do so was a special one. After those fourteen years in academic life I was called to become Bishop of the Protestant church in Berlin - which was

\footnotetext{
4 On the relationship between the Barmen Theological Declaration (1934) and the Belhar Confession cf Koopman 2009:60-71, Smit 2006a:91-302. For the general overviews by Smit 2007b:840-844 and 2006b:322-332.

5 The BelharConfession states, among under things, "that the credibility of this message is seriously affected and its beneficial work obstructed when it is proclaimed in a land which professes to be Christian, but in which the enforced separation of people on a racial basis promotes and perpetuates alienation, hatred and enmity; that any teaching which attempts to legitimate such forced separation by appeal to the gospel, and is not prepared to venture on the road of obedience and reconciliation, but rather out of prejudice, fear, selfishness and unbelief, denies in advance the reconciling power of the gospel, must be considered ideology and false doctrine" (Naudé 2010:221f.).
} 
NGTT Deel 54, Nommers 3 \& 4, September en Desember 2013

to become in that time the German capital once again - and for the rural Brandenburg area surrounding the city. This position I filled for sixteen years, the last six years of which I also served as President of the Rat der Evangelischen Kirche in Deutschland (Council of the Evangelical Church in Germany), ending in November 2009.

I was exposed to political quarrels right from the beginning: How to deal with political refugees when they are not legallyrecognised as asylum seekers? AreChristian congregations allowed to grant them sanctuary until their cases are eventually reopened? This was one of the initial conflicts I had to deal with. This first issue already implied a question regarding Christian partiality towards the matter of foreigners in public discourse or even before the judiciary. How to uphold Christian ethics in a pluralistic, highly secularised public arena became one of the main dimensions of my ministry in all those years.

Over the past ten years, bioethics has turned out to be one of the important fields in such a discourse. Embryonic stem cell research, pre-implantation diagnosis and euthanasia were among the themes that in many countries have led to considerable ethical disagreements and heated public debates. These debates and disagreements present clear evidence of pluralism in ethics. Amongst the questions raised was: Do Christian ethics matter at all? It is the Christian position that embryonic lifealready shares in the respect for human dignity owed to all. If so, does this have consequences for legal restrictions on the possibilities for embryonic stem cell research? Furthermore, does public discourse have to be limited to so-called secular or neutral arguments? If so, which arguments are secular or neutral? Is the reference to human dignity secular - and is it clear how humanity is relevant to the questions that I have mentioned?

Another similar example was the debate on the implications of the global financial and economic crisis of the past two to three years. Can the preferential option for the poor proclaimed by Christian ethics be mediated into public discourse? Should there be a Christian position on the remuneration system in investment banking or on an upper limit for the salaries of industry executives? (cf. Huber 2010).

The last example I want to mention is the new awareness of a Muslim presence in European countries. This awareness has changed profoundly after 11 September 2001. Whereas the size of the migrant population in Germany used to be calculated according to the numbers of Turks, Iranians, Russians or Italians, migrants from countries with a Muslim majority nowadays generally feature as "Muslims" in these calculations. Thus, the creation of stereotypes of cultural identity occurs in a very significant way. This has consequences for the way in which Muslims organise themselves in a country such as Germany, as well as for dialogue between Christians and Muslims.

After the above three periods of professional experience - twelve years as a church-related researcher, fourteen years as a full-time professor of ethics and sixteen years as a church leader - I feel a duty to address the role of Christian ethics for society anew. In my next period of research and public involvement I want to take the pluralistic character of modern societies even more seriously than I did in some of my previous approaches. However, in order to reach some ethical agreement in pluralistic societies, we have to make room for the different voicesto be heard. For only then we shall find a relevant, overlapping consensus amongst these voices. ${ }^{6}$

6 The concept of an "overlapping consensus" was first developed by John Rawls in his essay The Idea of an 
NGTT: Oopbron - http://ngtt.journals.ac.za

Another aspect is relevant in a similar way. We will not succeed in promoting some kind of ethical behaviour in people's personal lives and in society without mobilising the motivational forces embedded in the deep convictions of human beings - whether these convictions be based on religion or something else. Ethics has to do not only with the question of what one should do, but even more with the question why we should do so. In the obvious crisis of social coherence we experienced in many societies characterised by a high degree of diversity, the ethical problem has to do not only with ethical pluralism or a lack of moral standards, but even more - as the New York philosopher Simon Critchley calls it - with a "motivational deficit" (cf. Critchley 2007:2ff.). ${ }^{7}$ In my view this is one of the obvious points of comparison between the present situation in South Africa and in Germany.

In both societies this observation applies to young males in particular. In different forms and to a different extent a lack of constructive perspective, a feeling of not being needed by society and not knowing what the purpose of one's life is lead to a period in the lives of especially of young males when they may be called "youth at risk" (cf. Duckenfield and Swanson 1992; Brendtro, Brokenleg and Von Bockem 2002). It is probably not that young people do not know that physical violence is a crime, that rape brutally violates the integrity of its victims, that robbery is an act of unacceptable aggression or that xenophobia blatantly contradicts human dignity. In reality, ethical pluralism does not go so far as to make these moral insights controversial. Instead, it is rather a case of the experience of social exclusion, of a lack of being morally embedded or of lacking a personal outlook for the future that produces these kinds of motivational deficits and these depressing forms of social anomia.

How can these social conditions be changed? Also, how can ethically acceptable options be clarified and motivated? These seem to be the tasks at the heart of our common problems in societies with both high diversity and a lack of social cohesion, be it South Africa, Germany or other pluralistic societies.

\section{ETHICS IN A "TIME OF MANY WORLDS"}

Calling contemporary societies "pluralistic" cannot be taken for granted at all. The Chicago ethicist William Schweiker calls the present time a "time of many worlds" (Schweiker 2004). He uses a metaphor that has grown in its attraction since we became used to distinguish between a First, Second and Third - or even a Fourth - World. But irrespective of the metaphorical attraction of this way of speaking, we live only in one world. The oneness of this world is underlined even when we take into account other possible kosmoi (cf. for example, Ellis, Kirchner and Stoeger 2004:921-936), or when Christian faith upholds the hope for a world to come that will transform the current one (Rev. 21:1). Therefore, we have to proceed from the metaphor of a "time of many worlds" towards a (hopefully) clearer description but which one?

I put aside the description of our time as being "postmodern". I do so not only because I have begun to increasingly doubt post-terminologies in general, but even more because, in the case under discussion here, the term used for descriptive reasons already prescribes what we should think in normative terms. "Postmodernism" makes it meaningless to ask for common

Overlapping Consensus (1987)Cf. John Rawls (1996).

7 It was Dirkie Smit who encouraged me to read Simon Critchley, as is the case with Kwame Anthony

Appiah whom I cite later on. 
NGTT Deel 54, Nommers $3 \& 4$, September en Desember 2013

moral perspectives or for an ethical overlapping consensus because we know in advance that the great narratives are something of the past (namely modernity) and, therefore, that any narrative can unfold its meaning only for a specific community, existing more or less separately next to others (cf. Lyotard 1984). Therefore, I do not plan to work with the concept of postmodernism because I got the impression that it does not offer sufficient room for the question of social coherence between or mutual respect for and by those who differ from each other.

Nowadays, many people start describing our time by referring to the notion of globalisation. This term seems to be appropriate for a time in which the international order (or disorder) is no longer shaped by competition between two superpowers and their allies, but by a multitude of global actors. Furthermore, this concept takes into account that global actors are not necessarily only political bodies, but also include economic actors that combine a great deal of power with the minimum of public control and democratic accountability.

The fact that economic globalisation is the driving force of contemporary developments can be highlighted from different perspectives. Those who claim a growing independence of economic decisions from political control blame it on globalisation. Those who are convinced that today's global economy undermines the demands for social justice also use globalisation as framework for their critique - from directly the opposite perspective!

In both cases globalisation is used to explain diversity. In one case it is regarded from the perspective of diversity in competition. By means of growth and profit every global player tries to gain the upper hand in a special field - be it Germany's role as "world champion" in export in general, or South Africa's role as the world's premier exporter of gold and platinum. From the other perspective, globalisation is explained with reference to the diversity of disparity: the inequality between a small minority growing richer and richer and a majority becoming increasingly poorer and poorer (at least in comparison), with a shrinking middle class in between. $^{8}$

However different these two perspectives may be, they do share the characteristic of looking at the human condition from a merely economic perspective. The globalisation approach is consciously monothematic. Either for the benefit of affirmation or for the benefit of critique it reflects an image of society formed according to the idea of the homo oeconomicus.

Another very surprising way of describing diversity in society gained popularity over the last few of years. It uses terminology relating to culture. Group membership is seen as the decisive criterion for diversity. Gender, sexual orientation, ethnicity, race, and religion are the main criteria employed to evaluate this diversity. The term "culture" is used as an umbrella term for listing such heterogeneous criteria. Astonishingly, in a time when cultural diversity in a narrower sense is diminishing in many societies - due to the combined effects of modern mass communication and mass consumption - the word "culture" in a very general sense is used to cover all kinds of diversity. Princeton philosopher Kwame Anthony Appiah reminds his readers that "culture", used in such a general way, is a rather new and clearly Western concept (Appiah 2005:114ff.). The term goes back to German Romanticism, which was not really a multicultural intellectual movement that identified a certain people (the Volk) with its culture. Later, as we know, this assumption became an attractive one for some Afrikaners in South Africa. Around

8 For this perspective, cf. the Stellenbosch project on globalization in Boesak and Hansen 2009 cf. also Smit 2007a:192-209. 
NGTT: Oopbron - http://ngtt.journals.ac.za

the time of World War I, the strong link between the German people and its culture contrasted with Western civilisation in general. The idea that culture is superior to civilisation has its origins in this debate. In the meantime, this idea has changed into the conviction that culture is more basic to human life than civilisation. Therefore, the term "culture" has been incorporated into most languages of the world. Kwame Appiah uses Asante - one of the languages spoken in his native country, Ghana - to illustrate this (Appiah 2005:119). However, the ubiquitous use of the term "culture" deprives it of any clear contours.

There is no doubt that the identities of human beings are formed by the groups they belong to, the traditions they grow up with, the languages they speak, the songs they sing, the God(s) they worship. But is it really convincing to deduce from the relational character of human identity that one of these group memberships can be distinguished from all others as the decisive one responsible for a collective identity? As mentioned earlier, after 9/11 people of Turkish decent in Germany came to be identified not by their "Turkishness", their migration background or their economic position in society, but mostly by the assumption that they all are Muslim. It is this reductionist effect of the paradigm of multiculturalism that worries me. The awareness of cultural diversity found at the outset of the discourse on multiculturalism has changed over time into a one-dimensional understanding of human identity.

Nobel Laureate Amartya Sen begins his book Identity and Violence, which deals with this "solitarist approach" to human identity, by telling about his return to England from a trip abroad in the time when he was Master of Trinity College in Cambridge (Sen 2006:1). The immigration officer at Heathrow scrutinised his Indian passport and ended up by looking at his address in Britain: Master's Lodge, Trinity College, Cambridge. On seeing his address, he expressed his surprise in the form of a question - namely whether the Master whose hospitality this Indian citizen enjoyed was a close friend of his. Amartya Sen tells of the kind of philosophical reflection this question triggered in himself, namely: Are you the friend of yourself?

If a question regarding a person's personal identity can lead to complications such as these, it is even more so with regard to social identity. When we move from the notion of "being identical to ourselves" to "sharing an identity with others" we have to be cautious. A one-dimensional interpretation of this shared identity is often combined with a sharp dissociation from others. An identity of this kind easily ends in conflict, hatred, aggression and destruction. It is one of the driving forces behind physical violence. Any kind of monothematic interpretation of social identity is bound to strengthen such a dangerous move towards hostile, irreconcilable identities. In our day religious identities in many places are driven to play such a role. Whether they really remain at the root of a conflict or not, religious identities play a conflict-enforcing role. Much too often they are also used as instruments pushing in that direction.

Over the years I became sceptical of the concept of multiculturalism. We need some idea of the individual in order to overcome the collectivist misunderstanding that sharing an identity with others means to be completely identified with this collective group identity. In real life we share certain aspects of our identity with certain groups, but regarding others we differ. We may share a religious affiliation with some group, but differ regarding the rugby team we support. We may belong to a certain professional group, but differ in political preferences from many members of this group.For a long time I have been opposing a narrow, individualistic understanding of the human person. I continue to do so. I remain 
NGTT Deel 54, Nommers 3 \& 4, September en Desember 2013

convinced that the human self is relational by its very nature. We depend on others from the very beginning of our lives until their veryend. As self-transcendent beings we interpret our relational existence within the framework of being created in God's image - or we use other, even contradictory ways to understand and explain it. However, the variety of our social bonds is not and should not be restricted to one single relation determining our identity. To avoid this kind of identity determinism we need a strong emphasis on the individual character of the human person. Consequently every use of the concept "multiculturalism" should be balanced by the insight that the diversity of human societies basically consists in their multi-individuality. We are "diversely different", to quote Amartya Sen once again (2006:1).

Why I see the responsible, relational self (instead of irresponsible, individualistic self) as the basic unit of an ethics of responsibility for pluralistic societies will be one of the themes I intend to focus on in the years to come. For now.

\section{FROM ETHICAL PLURALITY TO PLURALISTIC ETHICS}

Given this diversity in societies such as South African or German society one should not be surprised to find this diversity reflected in ethical pluralism. Whereas in former times pluralism in society mostly was described as a pluralism of conflicting interests - capital and labour being the most important - today it is often said that the pluralism of convictions, world views, ethical orientations and religious affiliations are the strongest elements of pluralism as such. The Pluralism Project at Harvard University, for example, concentrates exclusively on religious diversity ${ }^{9}$ the Stanford Encyclopaedia of Philosophy also explains the term "pluralism" only with reference to religious diversity. ${ }^{10}$

I will not dare to give such a clear priority to one or the other dimension of diversity in society. In any case, it is not at all surprising that this diversity is reflected in the form of ethical pluralism with differing ethical claims, which may be either compatible or incompatible. There is nothing new about this kind of ethical pluralism. Amartya Sen, in his The Idea of Justice, quotes Shakespeare's King John: "Well, whiles I am a beggar, I will rail / And say there is no sin but to be rich; / And being rich, my virtue then shall be / To say there is no vice but beggary" (Sen 2009:196f.). Sen also uses almost as a motto for his book the example of three children and one flute. All three children claim the flute, but each bases their claim on quite different reasons: Anna knows how to play flute, Bob is the poorest of the three, and Carla made the flute herself (Sen 2009:13). Is that not an excellent example of an ethical dilemma?

However, it is only the built-in structure of ethical dilemmas that leads to ethical pluralism; the growing diversity within society creates an even greater degree of ethical pluralism. Different strategies exist to deal with this. The most prominent strategies are found in hard exclusivism, on the one hand, and in hard relativism on the other.

Hard exclusivism - often called "fundamentalism" - refers to the position that, amongst a variety of competing truth claims, only one can be acceptable. In history this position has opened the door to intolerance and inquisition. In opposition to this strategy developeda modern understanding of human rights that has as centre the recognition of freedom of religion and conscience. Unfortunately this development has not hindered the resurgence

9 online at: http://pluralism.org/.

10 The key word "pluralism" leads immediately to "religious diversity". Cf. Zalta 2011. 
NGTT: Oopbron - http://ngtt.journals.ac.za

of new forms of exclusivism that react to the complexity of modern societies with a return to clear, seemingly undeniable truth claims. Whoever denies such truth claims becomes separated from the truth and, therefore, from the possibility of being truly human. The eventual violent consequences of such exclusivism are obvious.

Hard exclusivism stands opposite to hard relativism, which denies the possibility of any truth claim in the field of ethics or other basic convictions, be they religious or secular. At first glance this seems a very pragmatic approach: "Let all be saved in their own way!" said a Prussian king to justify his kind of religious tolerance. ${ }^{11}$ Unfortunately, a pure relativism does not take the functioning of strong convictions seriously enough. It applies relativity to spheres of human existence where exactly the opposite usually happens. Very few people will see their deep and strong convictions as something relative. And at the same time relativism does not take seriously enough the problem of social cohesion and human coexistence. To make a life together possible, people need shared convictions; they look for common rituals and need at least minimal shared standards of behaviour. For every human community a common moral basis and a common understanding of how to deal with differences seem to be indispensable.

Some search for a way out of the impasse between exclusivism and relativism by espousing a kind of neutrality. Their proposal is to restrict public discourse to arguments that they call "purely rational, secular or neutral". They declare religious convictions to be a private matter that should not be brought into the public sphere. A common understanding of such rump morality ("morality in the sense of 'what we owe to each other"' - Appiah 2005: xiii quoting Scanlon) can be reached according to this strategy by way of minimal agreement. However, religious convictions are not purely a private matter; on the contrary, they are of remarkable public relevance - especially nowadays. Nor is it meaningful to search for ethical solutions to the challenges of our time without using the sources of religions, humanistic world views, secular convictions, et cetera. It is in this regard that Jürgen Habermas hints at the deeper sources of solidarity in religions for which the enlightened morality of equal respect for all or other forms of secular ethics - in his view, as a Protestant turned agnostic - seemingly do not present a motivational equivalent (see Habermas 2008; 2009a:137-147; 2009b:387-407; Mendieta 2010; Calhoun, Mendieta and Van Antwerpen 2011).

Indeed, a modern constitutional order is secular by its very nature. However, this does not imply that public discourse must be restricted to secular arguments. The secular option is only one option among others within society, and it should not be the general prerequisite for participation in public discourse. Religions, and (in South Africa, as in many parts ofEurope) the Judeo-Christian tradition in particular, played a major role in the search for a democratic society based on equal freedom for its members. Not only for genealogical reasons, but also because such traditions continue to be relevant sources of orientation, a society should exclude neither its wisdom nor the critical analysis of its failures from public discourse.

This reflection leads us from ethical pluralism to pluralistic ethics. In order to find common ground regarding human and societal diversity, we have to understand the term "pluralism" not only in a descriptive sense but also in a normative sense. We have to acknowledge the "fact of reasonable pluralism" (Rawls 1996:188f.) and search for ways to deal with it. Pluralism then becomes reflexive and is understood not only as a fact but also as a task. This task can be summarised as the simple challenge to live together amidst diversity.

11 The quotation originates from King Friedrich II (1712-1786): "Die Religionen Müsen alle Tolleriret werden und Mus der Fiscal nuhr das Auge darauf haben das keine der andern abrug Tuhe, den hier mus ein jeder nach seiner Fasson Selig warden". 
NGTT Deel 54, Nommers 3 \& 4, September en Desember 2013

It is for this purpose that an old distinction has attracted new attention, namely the distinction between morality and ethics. Ronald Dworkin describes this distinction in a classic way by saying that ethics "includes convictions about which kinds of lives are good or bad for a person to lead, and morality includes principles about how a person should treat other people" (Dworkin 2000:485, fn.1; cf. Appiah 2005:xiii). Morality has to do with the question "what we owe to each other" (Scalon 1998); ethics has to do with the question as to what it means for a person to lead a good life. Whereas the first of these two questions (the question of morality) needs answers that can be universalised, the second one (the ethical question) needs answers that may differ from person to person, from culture to culture, from religion to religion. Thus, all kinds of ethics need to include universalistic positions, but this they do on different grounds. They even have to be open to the different interpretations stemming from different cultural or religious backgrounds - otherwise they will be universalistic in theory only and not in practice. What we need in this respect is what I call "a perspective universalism" - that is a universalism open to different perspectives on our common humanity.

In daily life we regularly do not distinguish morality from ethics. Our ethical reflection includes both types of questions. Andethics - religious or otherwise-include both elements. Christian ethics, for example, include the Golden Rule (Mt. 7:12) as well as the commandment to love God and to love our neighbour as ourselves (Mt. 22:37-39). An ethics that includes morality as well as the ethical in the narrow sense can develop the capacity to respect difference and to deal with the coexistence of people who differ from one another. In this precise sense it can develop into a pluralistic ethic, namely an ethics for living together amidst diversity. Christian ethics, in my understanding, are obliged to take this direction. Thus I come to my final brief observation.

\section{THE DIGNITY OF DIFFERENCE OR THE DIGNITY OF THE DIFFERENT}

The guiding idea for my reflections on a Christian ethics for pluralistic societies is the dignity of the different. The Christian understanding of the human person is based on the conviction that all human beings are created in the image of God, as creatures corresponding to God, as responsive and responsible selves. They are ends in themselves and not merely means to alien purposes. That is what human dignity is all about.

It has often been emphasised that every understanding of human dignity has to be inclusive. The term "dignity" itself is taken seriously only when it applies to all human beings equally. Jürgen Habermas, among others, has emphasised that this egalitarian universalism is a specific contribution of Judeo-Christian thinking to modernity. ${ }^{12}$

However, just as important as this emphasis on the equal dignity of all human beings is the equal dignity of the different. Human beings have to respect and to love, to protect and to

12 Jürgen Habermas (2006:150f.): “Christianity has functioned for the normative self-understanding of modernity as more than a mere precursor or a catalyst. Egalitarian universalism, from which sprang the ideas of freedom and social solidarity, of an autonomous conduct of life and emancipation, of the individual morality of conscience, human rights, and democracy, is the direct heir to the Judaic ethic of justice and the Christian ethic of love. This legacy, substantially unchanged, has been the object of continual critical appropriation and reinterpretation. To this day, there is no alternative to it. And in the light of the current challenges of a post-national constellation, we continue to draw on the substance of this heritage. Everything else is just idle postmodern talk." 
NGTT: Oopbron - http://ngtt.journals.ac.za

promote each other in their otherness. Respect for the uniqueness of the other is at the core of respect for their dignity. It is only in this way that one can see human dignity as a guiding principle for a radically pluralistic - that is, a multi-individual - society.

In 2002 Sir Jonathan Sacks, now for nearly two decades Chief Rabbi of the United Hebrew Congregations of the Commonwealth, published a book under the title The Dignity of Difference (Sacks 2002). This phrase also occurs in comments by Archbishop Thabo Makgoba, the Anglican Archbishop of Cape Town, who sees the sanctity of life, the integrity of creation, and the dignity of difference as the three essential points of departure of Christian ethics (Makgoba 2010). Sacks links the phrase "dignity of difference" to the difference of cultures, mainly religions. He repeats the fear that those differences may lead to a "clash of civilisations", as Samuel Huntington predicted. But, he says, every one of those cultures echoes and reaches out to God in its own ways. Thus Sacks speaks about the dignity of difference.

I would argue, however, that not every difference is good and acceptable or should be "dignified". Not all diversity has a place in an "ordered complexity", to use Sacks' phrase. The question is not whether differences of culture have an inherent dignity, but whether those cultures respect the equal dignity of human persons.

Cultures often reflect the brokenness of human existence; they even express the selfishness of human endeavours and become instruments of the arrogance of superiority. Therefore, not the dignity of difference but the dignity of the different should, in my view, be respected as a guiding moral principle in the twenty-first century - a "time of many worlds".

\section{BiBLIOGRAPHY}

Heidegger, M. 1996. Being and Time, tr. Stambaugh, J. New York, NY: State University of New York Press. Kant, I. 1999. Beantwortung der Frage: Was ist Aufklärung? Ausgewahlte kleine Schriften, Cassirer, E. and Brandt, H. D. (eds.). Hamburg: Felix Meiner, 20-27.

Lasor, W. S., Hubbard, D. A. and Bush, F. W. M. 1994. Old Testament survey. The Message, Form, and Background of the Old Testament. Grand Rapids, MI: Eerdmans.

Mbiti, J. 1969. African religions and philosophy. London: Heinemann.

Naudé, P. J. 2007. The Challenge of Cultural Justice under Conditions of Globalization: Is the New Testament of Any Use? In Breytenbach, C., Thom, J. and Punt, J. (eds.), The New Testament Interpreted: Essays in Honour of Bernard C. Lategan. Leiden: Brill, 267-287.

Naudé, P. J. 2010a. Fair Global Trade: A Perspective from Africa. In Moore, G. (ed.), Fairness in International Trade. London: Springer, 99-116.

Naudé, P. J. 2010b. Neither Calendar nor Clock. Perspectives on the Belhar Confession. Grand Rapids, MI: Eerdmans.

Rawls, J. 1999. The Law of Peoples. Cambridge, MA: Harvard University Press.

Smit, D. J. 1975. Demokrasie en Dialoog. (Democarcy and Dialogue.) Unpublished MA thesis in Philosophy, Stellenbosch University Press.

Smit, D. J. 1979. Teologie as Antropologie? 'n Kritiese Waardering van Karl Rahner se TransendentaalAntropologiese Teologie. (Theology as Anthropology? A Critical Appreciation of Karl Rahner's Trancendental-Antropological Theology.) Unpublished doctoral dissertation in Systematic Theology, Stellenbosch University Press.

Smit, D. J. 1984. In a Special Way the God of the Destitute, the Poor, and the Wronged. In Cloete, G. D. and Smit, D. J. (eds.), A Moment of Truth: The Confession of the Dutch Reformed Mission Church, 1982. Grand Rapids, Ml: Eerdmans, 53-65.

Smit, D. J. 1989. Om Saam met Al die Heiliges Christus te Ken (To Know Christ Together with All the Saints In Theron, P. F. en Kinghorn, J. (reds.): Koninkryk, Kerk en Kosmos. (Kingdom, Church and Cosmos.) Bloemfontein: Pro Christo, 11-32. 
NGTT Deel 54, Nommers $3 \& 4$, September en Desember 2013

Smit, D. J. 1992. Reformed Theology in South Africa: A Story of Many Stories. Acta Theologica 12(1), 88110.

Smit, D. J. 2006. Apartheid. In Betz, H. D., Browning, D. S., Janowski, B. and Jüngel, E. (eds.), Religion Past and Present. Vol. 1. Leiden: Brill Academic, 293-295.

Smit, D. J. 2007. Essays in Public Theology. Collected Essays I. Conradie, E. M. (ed.).Stellenbosch: Sun Press.

Smit, D. J. 2008a. Apartheid. In Betz, H. D., Browning, D. S., Janowski, B. and Jüngel, E. (eds.), Die Religion in Geschichte und Gegenwart (Band 1), Studienausgabe. Tübingen: J.C.B. Mohr (Paul Siebeck), 580-582.

Smit, D. J. 2008b. Confessional and Ecumenical? Revisiting Edmund Schlink on the Hermeneutics of Doctrine. Verbum et Ecclesia 29(2), 446-474.

Smit, D. J. 2008c. Geloof en Openbare Lewe. Versamelde Opstelle II. (Faith and public life. Collected Essays II.), Koopman, N. N. (ed.). Stellenbosch; Sun Press.

Smit, D. J. 2008d. Hoe Vertel Hulle die Storie? Oor Karl Barth. (How are They Telling the Story? On Karl Barth.) Scriptura 98(2), 174-184.

Smit, D. J. (with Koopman, N. N.) 2008e. Human Dignity and Human Rights as Guiding Principles for the Economy? Comments from a Theological Perspective. In Le Bruyns, C. C and Ulshöfer, G (eds.), The Humanisation of Globalisation - South African and German Perspectives. Frankfurt: Haag und Herchen, 59-70.

Smit, D. J. 2009a. Essays on Being Reformed. Collected essays 3. Vosloo, R. R. (ed.).Stellenbosch: Sun Press.

Smit, D. J. 2009b. In die Geskiedenis Ingegaan. (Gone into History.) In Conradie, E. M. and Lombard, C. (eds.), Discerning God's Justice in Church, Society and Academy. Festschrift for Jaap Durand. Stellenbosch: Sun Press, 131-165.

Smit, D. J. 2009c. Theological Assessment and Ecclesiological Implications of the Accra Document "Covenanting for Justice in the Economy and the Earth". Tentative Comments for Discussion. In Boesak, A. A. and Hansen, L. D. (eds.), Globalisation. The Politics of Empire, Justice and the Life of Faith. Stellenbosch: Sun Press, 173-184.

Smit, D. J. 2010. Trends and Directions in Reformed Theology. The Expository Times 122(7), 1-14.

Transparency International Corruption Perception Index. Online at: http://www.transparency. org/ policy_research/surveys_indices/cpi/2010.

United Nations Human Development Index. Online at: http://hdr.undp.org/en/data. Westermann, C. 1974. Genesis. Band I/1. Neukirchen-Vluyn: Neukirchener.

\section{KEY WORDS}

Ethics

Pluralistic societies

Public Theology

Dignity of the different

\section{TREFWOORDE}

\section{Etiek}

Pluralistiese samelewings

Publieke Teologie

Waardigheid van die anderse

Contact Details/Kontakbesonderhede

Prof Wolfgang Huber

C/o Stellenbosch Institute for Advanced Study (STIAS)

Wallenberg Research Centre

Stellenbosch University

Marais Street

7600 Stellenbosch

E-pos: secretariat@wolfganghuber.info 